\title{
Patent Oppositions in India
}

\author{
Sandeep Kanak Rathod
}

\begin{abstract}
Pre-grant and post-grant oppositions filed in India by civil society and generic companies have been instrumental in visibly increasing access of drugs to the public_-both in terms of earlier generic entry and also cheaper prices due to such generic competition. This paper looks at the significant pharmaceutical patent oppositions in India during the last 15 years. It focuses on some unique aspects connected to each of these oppositions and tracks how these oppositions helped in securing earlier access to generic drugs. The last part of the paper analyses patent opposition pendency statistics and notes that increasing pendency numbers, over the last few years, is a matter of deep concern as it could impact access to drugs, in future.
\end{abstract}

\section{Introduction}

Patent oppositions by civil society organisations and generic pharmaceutical companies have been instrumental in increasing access of drugs to the public-by preventing patent evergreening and bringing in earlier generic drug entry as well as increasing competition in the pharmaceutical sector leading to cheaper prices due to such generic entry. Over the years, various commentators have written on Indian patent oppositions-from different legal and policy perspectives. ${ }^{1}$

In this paper, the author analyses key pharmaceutical patent oppositions in the last one and half decade and shares certain lesser discussed angles of these oppositions. The paper is divided in two parts. The first part discusses important pharmaceutical patent oppositions pertaining to drugs across disease categories and looks at how legal arguments have progressed moving beyond the simplistic statutory arguments as well as how certain strategies that are beyond the opposition framework can lead to successful results even when an opposition is not filed.

\footnotetext{
${ }^{1}$ Below are some papers that have looked at patent oppositions in India from different perspectives: Amin (2010); Ho (2011); Ali (2016); Serrano and Burri (2019), pp. 275-294.
}

S. K. Rathod $(\bowtie)$

Mumbai, India

(C) The Author(s) 2022 
The second part of the paper looks at the current opposition pendency statistics and what these statistics mean for oppositions for the times to come. Before proceeding further, it is important to note that India, like many developing countries, has a healthcare system where individuals pay a very large proportion of healthcare expenses from their pocket. ${ }^{2}$ This reality combined with a large population, means that the drug access mechanism becomes that much more strained and every attempt at increasing drug access needs to be seen not only in the limited framework of intellectual property (IP) but in the broader framework of living in a resource constrained country.

India has a long history of patent law, going back to the $1850 \mathrm{~s}^{3}$ The present patents regime in India is enshrined within the Patents Act, $1970^{4}$ ('the 1970 Act') that was enacted after repealing the Indian Patents and Designs Act 1911. After independence in 1947, India set up committees to look at the 1911 Act and these committees noted the stage of economic development in India, the relevance of patents to a country that was then not an industrially developed nation and what possible changes could be made to the 1911 Act. The Ayyangar Committee Report ${ }^{5}$ also noted the disparities resulting from the 1911 Act and how certain steps were necessary to completely rewrite the statute. Importantly, this Report recommended moving to a 'process claims' only regime for certain sectors ${ }^{6}$ and was the foundation for the 1970 Act.

The 1970 Act allowed only process patents within the drug/pharmaceuticals and food domain, until 2005. Changes were made in stages to the 1970 Act in 1999, 2002 and 2005 as a part of India's commitments to the Trade Related Aspects of Intellectual Property Agreement (TRIPs Agreement) and India restarted issuing product patents for pharmaceuticals and allied sectors from 2005.

\footnotetext{
${ }^{2}$ As per the National Health Accounts (NHA) estimate for 2014-15, Out-of-Pocket Expenditure (OPE) per person, per year in India, is Rs. 2394, which comes out to be $63 \%$ of the total health expenditure.

Reference: <https://www.downtoearth.org.in/dte-infographics/india_s_health_crisis/index. html $>$.

The World Bank data also gives a similar figure (of $62.4 \%$ as OPE-latest data pertained to year 2017): <https://data.worldbank.org/indicator/SH.XPD.OOPC.CH.ZS?end=2017\&locations $=$ IN\& start $=2000 \&$ view $=$ chart $>$.

${ }^{3}$ The 'background' section has been adopted from author's earlier article: Compulsory licences on pharmaceutical patents in India: A short article. Journal of Generic Medicine, 13(3), 108-113. doi: $10.1177 / 1741134317691804$.

${ }^{4} \mathrm{~A}$ copy of the statute is available at the Indian Patent Office' website: <http://www.ipindia.nic.in/ acts-patents.htm>.

${ }^{5}$ 'Report on the revision of the patents law' by Justice N. Rajagopala Ayyangar; released in September 1959 and available at <http://www.ipindia.nic.in/writereaddata/Portal/Images/pdf/ 1959-_Justice_N_R_Ayyangar_committee_report.pdf $>$.

${ }^{6}$ The Report discussed the background and rationale for moving from product claims to a process claims only regime for certain sectors, extensively-Refer Paragraphs 56 through 102 of the Report.
} 
Originally, oppositions came in the prosecution framework only once-i.e. after a patent application had already been examined and accepted by the Patent Office i.e. India allowed filing oppositions against 'applications accepted for grant'. India modified its patent opposition system in 2005 and created provisions for two types of oppositions-pre-grant opposition against a published application and post-grant opposition against a granted patent. In the earlier system, oppositions came in the prosecution framework only once-i.e. after a patent application had already been examined and accepted by the Patent Office. The modification thus allowed an opposition to be filed at an earlier stage of the prosecution framework as well as after the grant of patent.

Accordingly, a patent application can now be opposed under section 25(1) by filing a representation with the Patent Office. This is also normally called as a 'pregrant opposition'. A granted patent can be opposed under section 25(2) by filing an opposition. This is normally called as a 'post-grant opposition'. It needs to be filed within 12 months from the date of publication of such grant. A patent can also be sought to be revoked under section 64 and the Government can revoke patents on policy considerations under section 66 .

There are four main players within the patent opposition framework as applied to pharmaceutical inventions:

- The Government-Ministry of Commerce \& Industry, Government of India (which is ultimately responsible for the functioning of the Patent Office and grant of patents), the Ministry of Health and Family Welfare (responsible for health framework) and the Ministry of Chemicals and Fertilizers (that houses the Department of Pharmaceuticals);

- Innovator companies filing patents for their products (Applicants);

- Generic companies seeking to launch drugs as soon as possible (Opponents); and

- Civil society/Non-governmental organisations (also termed as 'NGOs') working at the grassroots on access to medicines and patient rights and who oppose patent applications/patents for ensuring drug access (hence, also Opponents).

Each of these players are important stakeholders and have different priorities/ goals within the patent system but each of them must play their roles with integrity and efficiency to create a system that balances drug access and health with encouraging an intellectual property (IP) rights framework to reward innovators.

The paper discusses 14 oppositions (both pre-grant and post-grant) that relate to important drugs that are needed by a large patient population. Oppositions for niche drugs are excluded. In most of the cases, companies had launched a generic version of the product, while the opposition proceedings were on-going and hence if the oppositions would have failed, it would have negatively impacted generic drug access.

As we trace these pharmaceutical oppositions, we note that many of the early oppositions filed in 2005-2015 were centered mainly around the statutory arguments 
from S. $3^{7}$ (which excludes from patentability certain inventions and is titled 'What are not inventions') and mostly around S.3(d) of the Patents Act (that bars grant of patents to new form of known substances or mere use of known processes).

Opponents have, over the years, moved beyond basing their case on S.3(d) alone and have gone to draft and win oppositions based on more complex arguments like lack of inventive step, obvious to try, anticipatory disclosures from markush claim ${ }^{8}$ filings etc. Just like the opposition arguments moved beyond 3(d), so have the patent examiners, for examination of pharmaceutical claims.

Published empirical research ${ }^{9}$ covering patent applications having priority dates between 2000 and 2012 advises that while examiners are invoking S. 3(d) more over time, but when they do so, it still tends to be in conjunction with novelty and inventive step objections. But effective use of S.3 and its implementation is an open question. A later paper ${ }^{10}$ covering pharmaceutical patents granted between 2009 and 2016 argues that the Examiners at the Patent Office have not been implementing S.3 framework to its fullest and that more than 70\% of such patents were in contravention of the anti-evergreening framework of S.3.

Hence, while one can try and imagine what would have happened in these 13 cases in absence of these oppositions; the undeniable fact is these pharmaceutical oppositions have expanded drug access for multiple important drugs- - not just for Indian patients but also for patients from other countries that are dependent on Indian generic drugs.

Within this scenario, increasing pendency statistics for oppositions, over the last few years, is a matter of deep concern as it could negatively impact drug access.

\section{Patent Oppositions in India}

\subsection{Gleevec Opposition}

Any paper on Indian patent oppositions can move forward only by starting from the Imatinib Mesylate Beta polymorph form opposition. Imatinib (brand name Gleevec)

\footnotetext{
${ }^{7}$ Section 3 of the Patents Act, 1970, is titled-'What are not inventions'. Section 3 is a 'deeming' fiction-it prohibits grant of patents to certain categories of inventions and is part of the chapter titled 'Inventions not patentable'. Thus, these inventions, in absence of this section would have been patentable. Text of S.3 is available at https://indiankanoon.org/doc/874310/. Within S.3, S. 3(d), 3 (e) and 3(i) have special importance as they relate to pharmaceutical inventions.

${ }^{8} \mathrm{~A}$ 'Markush' claim recites a list of alternatively useable members and can cover millions of compounds in a single claim. This can, at times, go much beyond actual embodiments exemplified in the patent specification. For a general discussion on what are markush claims, please refer https:// www.uspto.gov/web/offices/pac/mpep/s2117.html.

${ }^{9}$ Sampat and Shadlen (2018), p. e0194714.

${ }^{10}$ Ali et al. (2018).
} 
Table 1 Imatinib opposition

\begin{tabular}{l|l}
\hline Drug: & Imatinib \\
\hline Therapeutic area: & Anti-cancer/Oncology \\
\hline Nature of patent filing in India: & Beta crystalline polymorph of drug_Imatinib Mesylate \\
\hline Application \# & 1602/MAS/1998 \\
\hline $\begin{array}{l}\text { Date \& links to opposition } \\
\text { decision: }\end{array}$ & $\begin{array}{l}\text { 25/Jan/2006 } \\
\text { Natco: }<\text { https://indiankanoon.org/doc/1352538/> } \\
\text { Cipla: }<\text { https://indiankanoon.org/doc/1740470/> } \\
\text { Hetero: }<\text { https://indiankanoon.org/doc/1629598/> } \\
\text { CPAA: }<\text { https://indiankanoon.org/doc/994049/> }\end{array}$ \\
\hline $\begin{array}{l}\text { Expiry, if patent would have been } \\
\text { granted: }\end{array}$ & 17/July/2018 \\
\hline Opponent(s): & $\begin{array}{l}\text { Cancer Patients Aid Association }(\mathrm{CPAA}) \\
\text { Companies: Hetero, Cipla, Natco }\end{array}$ \\
\hline Unique points: & $\begin{array}{l}\text { Evidence submission, obviousness, disclosure versus claim } \\
\text { scope and S.3(d) }\end{array}$ \\
\hline
\end{tabular}

is a Novartis drug used in treatment of certain cancers (such as acute lymphoblastic leukemia, chronic myeloid leukemia, gastrointestinal stromal tumors etc.).

This opposition battle went all the way up to the Supreme Court of India ${ }^{11}$ where besides looking at the S.3(d) interpretation, the Court also made way for some very interesting case-law on inventive step, rejecting Novartis' arguments on disclosure v/s claim scope.

Filing details in Table 1:

The Indian Imatinib opposition saga starts after the grant of an exclusive marketing right (EMR) in December 2003 by the Patent Office to Novartis on its application for Beta polymorph of Imatinib Mesylate.

EMRs $^{12}$ were the predecessors of 'pharmaceutical product patent claims'. EMRs were brought into the statute book in 1999 as an interim mechanism to afford product patent type protection, after the United States' filed an action against India at the World Trade Organisation's Dispute Settlement Body in 1997. ${ }^{13}$ These EMRs could be granted only upon satisfying certain criteria and were to cease upon grant of product patent to the EMR holder, in due course.

The drug 'Imatinib', including its salts forms was invented at Novartis in 1993 and patents were filed for it in many countries. This patent was not filed in India since India did not allow product patent status for pharmaceutical products, in 1993.

\footnotetext{
${ }^{11}$ Novartis AG v. Union of India \& Ors. [2013] INSC 369. https://www.globalhealthrights.org/wpcontent/uploads/2013/04/SC-2013-Novartis-AG-v.-Union-of-India.pdf.

${ }^{12}$ EMRs were bought in via the 1999 amendment and covered in Chapter IVA (Sections 24A through F) of the Patents Act. The EMR chapter was removed in the 2005 amendment that reintroduced product patents for pharmaceuticals.

${ }^{13}$ Refer Nupur Maithani and Priyanka Vyas, 'India: Exclusive Marketing Rights Revisited in India' available at https://www.mondaq.com/india/patent/73894/exclusive-marketing-rights-revisited-inindia.
} 
Novartis' own experiments in 1996 had shown that there was no difference in efficacy between Imatinib and Imatinib Mesylate salt. It filed the Indian patent application for the Beta crystalline polymorph of Imatinib Mesylate in July 1998 and sought an EMR for the same from the Indian Patent Office, in March 2002. This 1998 patent filing was two steps away from the original 1993 invention-a move from Imatinib base to Imatinib Mesylate and then a move from Imatinib Mesylate to making a Beta crystalline polymorph of the same.

Meanwhile, Novartis had launched the drug in United States in 2001 and in India in April 2002. It got the EMR in December 2003. Some generic companies also launched the drug in India after Novartis' launch, but before the grant of EMR. There was a huge difference between Novartis' price and the price charged by generic companies.

Based on this EMR, in early 2004, Novartis went ahead with filing of infringement suits at two Courts - the Madras High Court (seven cases) and the Bombay High Court (three cases). The Madras High Court granted injunction(s) in favour of Novartis against such generic launches but the Bombay High Court did not grant injunctions. Multiple generic companies and civil society groups filed pre-grant oppositions against the pending application.

While journal articles have discussed nuances of the later court battles that came after the pre-grant opposition-including the Madras High Court ${ }^{14}$ decision(s), the Intellectual Property Appellate Board decision ${ }^{15}$ (IPAB) and the Supreme Court's decision, ${ }^{16}$ but there is very little written material on the actual pre-grant decision.

While the Opponents raised multiple grounds, two key questions raised were related to (i) S.3(d) and (ii) assessment of obviousness. S.3(d) brings in an additional question of examination when claims relate to new forms of known substances-in this case, claimed 'beta polymorph of imatinib mesylate' was a new form of known substance-Imatinib and its salts and would be eligible for patent only if the beta polymorph passed the framework of S.3(d) i.e. a patent could be granted only if the beta polymorph differed significantly in properties with regard to efficacy when compared to Imatinib or its known salts. The obviousness assessment for these claims was focused on the question of how making polymorphs of a known drug or its salt forms could be considered obvious to a person skilled in the art.

There is a notion that the opposition proceeding was superficial and did not give Novartis a fair chance to adduce evidence/data that it could not have put in the original patent specification. This notion is not based on facts. Actually, the Patent Controller (Mr. Rengaswamy), at first instance, had afforded an opportunity to Novartis to show the merits of the beta polymorphic form. Novartis could only show that there was a $30 \%$ improvement in bioavailability-i.e. the relative

\footnotetext{
${ }^{14}$ Basheer and Reddy (2008), pp. 131-155.

${ }^{15}$ The IPAB's decision was analysed here: https://spicyip.com/2009/07/breaking-news-novartisloses-glivec.html.

${ }^{16}$ The Supreme Court decision has been discussed below: (i) Ragavan (2013). http://works.bepress. com/srividhya_ragavan/156/. (ii) Attaran (2014), pp. 477-479. (iii) Grebe and Low (2017).
} 
bioavailability of Imatinib Mesylate in the beta crystalline form versus Imatinib free base (and not Imatinib Mesylate salt)—but could not show any specific therapeutic advantage of the beta crystalline form over Imatinib Mesylate itself. A salt form of a drug (regardless of its polymorphic form) would normally have increased bioavailability over a drug in its base form.

Importantly, in his decision, the Controller noted that '.. also the difference in bioavailability may be due to the difference in their solubility in water' and he held:

... As regards efficacy, the specification itself states that wherever B-crystals are used the imatinib free base or other salts can be used. The present patent specification does not bring out any improvement in the efficacy of the $\beta$-crystal form over the known substances rather it states the base can be used equally in the treatment of diseases or in the preparation of pharmacological agents wherever the B-crystal is used. Even the affidavit submitted on behalf of the Applicant does not prove any significant enhancement of known efficacy. It is found that this patent application claims only a new form of a known substance without having any significant improvement in efficacy. Hence I conclude that the subject matter of this application is not patentable...

Had these oppositions not been filed and Controller Rengaswamy not considered these key questions viz. (i) S.3(d) framework for assessing patentability arguments for new forms of a known substance and (ii) the law of obviousness for pharmaceutical inventions - then theoretically, the EMR and subsequent product patent would have sustained and possibly blocked generic launch until July 2018. While this opposition used S.3(d) extensively, the jurisprudence that developed from the Patent Office all the way up to the Supreme Court went a lot beyond the plain S.3 (d) argument.

Let's focus on some things that had their genesis from this set of pre-grant opposition(s). The filing of the pre-grant oppositions became the foundation for the later battles that led to the following important consequences:

- Securing earlier and consistent availability of generic version-from 2003 onwards and much before July 2018 (which would have been the expiry for the granted patent - thus earlier generic availability by a margin of 15 years);

- Bringing in a framework for examining obviousness while assessing pharmaceutical inventions;

- Creating jurisprudence on the concept of efficacy in pharmaceutical inventions and the difference between bioavailability and therapeutic efficacy (S.3(d));

- Laid the foundation for the Supreme Court to note that there cannot be a difference between what is disclosed in the patent specification versus what is claimed in the patent' claims.

This last point will again be in focus in the coming years-as Markush disclosures versus specific compound patent claim invalidation litigations are now pending the Indian Courts.

As noted earlier, literature has discussed extensively about the later high court, IPAB and Supreme Court battles of Imatinib. However, it is Controller Rengaswamy who was the first adjudicator/judge and made an important contribution that later 
Table 2 Valganciclovir opposition

\begin{tabular}{l|l}
\hline Drug: & Valganciclovir \\
\hline Therapeutic area: & Anti-viral \\
\hline Nature of patent filing in India: & Compound (L-valinate ester of Ganciclovir) \\
\hline Patent/Application \# & IN207232 (from 959/MAS/1995) \\
\hline Dates of decision(s): & $\begin{array}{l}\text { 2nd Pre-grant: 30/Jan/2009 } \\
\text { Post-grant: 30/April/2010 and again on 01/July/2015 }\end{array}$ \\
\hline Expiry, if patent remained granted: & 27/July/2015 \\
\hline Opponent(s): & $\begin{array}{l}\text { Indian Network of People Living with HIV/AIDS (INP+); } \\
\text { Companies: Matrix; Ranbaxy; Cipla and Bakul Pharma. }\end{array}$ \\
\hline Unique points: & $\begin{array}{l}\text { Ambit of 'Person interested' to file post-grant opposition, } \\
\text { Obvious to try and S.3(d). }\end{array}$ \\
\hline
\end{tabular}

became the cornerstone for India's pharmaceutical patent opposition/drug access saga.

\subsection{Valcyte Opposition}

Ganciclovir was approved as a drug in 1988. Roche later filed a patent application for a modification of Ganciclovir-i.e. it claimed the L-valinate ester of Ganciclovir (Valganciclovir, brand name: Valcyte). This drug is used in the treatment of adults in preventing infection with cytomegalovirus (CMV) that may occur after an organ transplant (heart, kidney, or pancreas). It is also used to treat CMV infection of the eye in adults with acquired immunodeficiency syndrome (AIDS). See Table 2.

This application saw the opposition fight in multiple rounds at the pre-grant stage and then a strongly contested post-grant opposition stage as well. And in the midst of this, there were rounds to the Madras High Court and the Supreme Court too.

In the first round, only a single short pre-grant opposition was filed by civil society groups (NGOs) in July 2006. The Controller rejected this opposition in November 2007 summarily and proceeded to process the grant of the patent. The civil society groups then moved the Madras High Court (HC) challenging this patent arguing that their pre-grant opposition was not heard by the patent controller. In December 2008, the HC asked the Patent Office to review its decision.

Roche decided to move the Supreme Court contesting the HC order ${ }^{17}$ which then directed the Patent Controller to consider the pre-grant opposition and dispose the case by 31/Jan/2009. The Patent Controller heard the matter again and through his decision dated 30/Jan/2009, rejected the NGOs' pre-grant opposition. Accordingly, the first set of pre-grant oppositions (in 2 rounds) did not succeed and a patent was granted to Roche.

\footnotetext{
${ }^{17}$ https://economictimes.indiatimes.com/industry/healthcare/biotech/pharmaceuticals/sc-asks-chen nai-patent-office-to-hear-roche/printarticle/4213952.cms.
} 
Meanwhile, Cipla had launched a generic version of the product in September 2008 and Roche filed a patent infringement suit. Subsequently, NGOs and multiple generic companies filed post-grant oppositions.

While the post-grant opposition was fought on multiple grounds including (a) S.3 (d) barred patenting of 'new' ester form of a known substance 'ganciclovir', in absence of enhanced efficacy and (b) an important obviousness argument was also bought in by a generic company (Matrix) which argued that making a valinate ester of a drug like Ganciclovir was obvious when seen from prior art construct of making a valinate ester of a drug like Aciclovir (an 'obvious to try' framework $\rightarrow$ Acicyclovir to its valinate ester-Valacyclovir approach would prompt a person to attempt to make the valinate ester-Valganciclovir-from Ganciclovir since these are similar drugs chemically and the underlying problem to be solved was similar) - this obviousness argument was eventually accepted by the Controller.

Apart from the science aspects noted above, a lesser known but key aspect in the post-grant stage was whether civil society groups had a 'standing' ('locus') to file a post-grant opposition as the Patents Act states that only a 'person interested' could file a post-grant opposition. Hence whether a non-manufacturing entity (like a civil society group) could come within the scope of 'person interested', thus having 'locus-standi' to file a post-grant opposition was, till then, an open question. To this question, the Controller specifically ruled that civil society groups came within the ambit of 'person interested'. This ruling expanded the scope of entities that could file a post-grant opposition and consequently civil society groups were now free to file post-grant oppositions.

The Controller, in the final Valcyte decision, not only revoked the granted patent and secured generic production, but also helped in expanding the ambit of the term 'person interested' and demonstrated how an 'obvious to try' argument could be effectively implemented for assessing patentability of alternative forms of known substances.

Roche appealed the post-grant rejection from the Patent Office to the IPAB, which remanded the matter back to the Controller. In July 2015, the Controller revoked this patent a second time ${ }^{18}$ which reconfirmed the earlier decision, including 'obvious to try' framework and the standing of civil society organisations to file post-grant oppositions as 'person interested'.

\subsection{Herceptin Opposition}

Trastuzumab (brand name: Herceptin) is a biologic drug (a monoclonal antibody) from Roche/Genentech, used primarily in the treatment of breast cancer. Roche had one Indian patent that covered a particular formulation of this drug. Roche hadover the years-filed multiple divisional applications from this original filing,

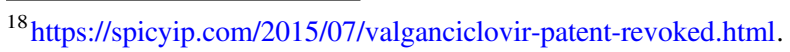


creating a series of pending divisional filings - each of which would have normally required filing separate oppositions, to secure launch of any generic product. Each of the three divisional filings suffered from individual procedural defects which meant that these were incorrect filings and should have not been allowed to remain in the system, in the first place.

A generic company (Glenmark) had filed a post-grant opposition against the granted patent, but that opposition never saw any traction at the Patent Office. Glenmark had also filed a pre-grant opposition against the first divisional application (1638), but this opposition too never reached the stage of a formal hearing.

Since late 2012, an NGO ('Campaign for Affordable Trastuzumab') had been working to increase access to Trastuzumab and was talking to the Government for the same. ${ }^{19}$ In March 2013, the Health Ministry had even recommended issuance of a compulsory license against the formulation patent ${ }^{20}$ but no compulsory license was issued on this patent.

In February 2013, a generic company had (Mylan Laboratories) bought the issue of all three divisional filings being incorrect in law, to the notice of the Patent Office by means of detailed letters. Consequently, the Patent Office invited Roche to explain its divisional filings. Roche did not attend the meetings in July 2013 and subsequently the Patent Office rejected the divisional filings. ${ }^{21}$ Roche had kept all of above Indian filings, active, from 2000 through July 2013.

In August 2013, Roche also abandoned its main patent ${ }^{22}$ (by opting to not pay renewal fee), but not before asserting ${ }^{23}$ that "This decision takes into account the strength of the particular rights and the IP (intellectual property) environment in India in general." Roche statement excluded any mention about Roche's rationale for originally filing and then abandoning these divisional filings or why it suddenly abandoned its main granted patent, for no specific reason.

Global media reports around the matter-led the Indian Patent Office to do something that it had never done (and has not done since). The Patent Office put out a press release (noted in Table 3) which systematically mentioned the defects in each of the Roche' divisional filings.

Roche's decision to originally prosecute and later abandon the Indian formulation patent as well as file and later abandon the multiple divisional applications (all of which it had kept alive for many years) - must be also seen in a broader context of corresponding filings outside India. While the above actions were going in India during 2012-13, Roche had been fighting an intense battle with Hospira (a generic company) first at the EPO (since 2006) and later also at the UK Courts for

\footnotetext{
${ }^{19} \mathrm{http}: / /$ www.pharmabiz.com/NewsDetails.aspx $?$ aid=77303\&sid=1.

${ }^{20}$ Refer Compulsory Licenses article, noted earlier, at pages 111 and 113.

${ }^{21}$ https://www.livemint.com/Companies/TBQxokHyVTMGozu78o6CSL/India-partly-revokesRoche-cancer-drug-patent.html.

${ }^{22} \mathrm{https} / / / \mathrm{www} . \mathrm{ft} . \mathrm{com} /$ content/b8c9cf06-0676-11e3-9bd9-00144feab7de.

${ }^{23} \mathrm{https} / / / \mathrm{www}$.reuters.com/article/us-roche-herceptin-india/roche-gives-up-on-india-patent-forbreast-cancer-drug-idUSBRE97F08220130816.
} 
Table 3 Trastuzumab opposition

\begin{tabular}{|c|c|}
\hline Drug: & Trastuzumab \\
\hline Therapeutic area: & Oncology (Breast cancer) \\
\hline $\begin{array}{l}\text { Nature of patent filing in } \\
\text { India: }\end{array}$ & Formulation for Trastuzumab \\
\hline Patent/Application \# & $\begin{array}{l}\text { 1. Original: IN/PCT/2000/391/KOL (matured into a patent } \\
\text { IN205534) } \\
\text { 2. 1638/KOLNP/2005—-first divisional application (child); } \\
\text { 3. 3272/KOLNP/2008—-second divisional application (i.e. first } \\
\text { grandchild); } \\
\text { 4. 3273/KOLNP/2008 — third divisional application (i.e. second } \\
\text { grandchild) }\end{array}$ \\
\hline Date \& Link: & Government Press Release dated 05/Aug/2013 (Krishnan 2013) \\
\hline $\begin{array}{l}\text { Expiry date, for the } \\
\text { granted patent: }\end{array}$ & 03/May/2019 \\
\hline Unique points: & $\begin{array}{l}\text { Filing of multiple divisional applications; Patent Office dismissed the } \\
\text { applications on procedural grounds }\end{array}$ \\
\hline
\end{tabular}

counterpart of this formulation patent. In October 2010, the EPO, in a first instance ruling, ruled this formulation patent (EP1308455), invalid. As of 2013, when Roche abandoned the Indian patent, its appeal against the invalidity decision, was pending at the EPO. In April 2014, ${ }^{24}$ the UK Patents Court, ruled the UK counterpart of the formulation patent as being invalid.

The author submits that while these abandonment/rejection results were achieved outside of the standard 'oppositions' framework, it must be noted that 'out of the box' actions/petitions can also achieve path-breaking results, even before/without filing an opposition. The Patent Office's decision of removing these incorrect divisional application filings and Roche' abandonment of the sole granted patent removed the need for filing multiple oppositions to the applications as well as the granted patent and thus cleared the way for launch of the world's first biosimilar Trastuzumab, in India in early $2014 .^{25}$

\subsection{Zykadia Opposition}

Ceritinib (brand name: Zykadia) is a Novartis drug used for treatment of lung cancer. This relatively recent post-grant opposition decision against Ceritinib compound patent is a short and interesting decision. See Table 4.

Natco had launched an 'at risk' generic version of Ceritinib in India, prior to this opposition decision. Novartis also has a patent infringement suit pending against

\footnotetext{
${ }^{24}$ [2014] EWHC 1094 (Pat), https://www.bailii.org/ew/cases/EWHC/Patents/2014/1094.html.

${ }^{25} \mathrm{https}: / / \mathrm{www}$.thehindubusinessline.com/companies/mylan-launches-first-trastuzumab-biosimilarin-india/article23122107.ece.
} 
Table 4 Ceritinib opposition

\begin{tabular}{l|l}
\hline Drug: & Ceritinib \\
\hline Therapeutic area: & Oncology \\
\hline Patent/Application \# & IN276026 (from 3951/DELNP/2009) \\
\hline Opponent: & Natco Pharma \\
\hline Dates of decision(s): & $16 / A u g / 2019$ \\
\hline $\begin{array}{l}\text { Expiry, if patent remains } \\
\text { standing: }\end{array}$ & 08/Dec/2026 \\
\hline Unique points: & $\begin{array}{l}\text { Anticipation—Markush disclosure versus specific compound; Lack } \\
\text { of inventive step and S.3(d) }\end{array}$ \\
\hline
\end{tabular}

Natco at the Delhi High Court. The opposition decision allowed Natco to continue to be present in market, but with the risk of payment of damages in future.

For the opposition, Natco used 3 main arguments-lack of novelty (anticipation), lack of inventive step and not an invention $\mathrm{u} / \mathrm{s} 3(\mathrm{~d})$.

For anticipation, Natco argued that two separate prior document(s): IN232653 (application \# 2241/CHENP/2005, coming from WO2004080980) and IN240560 (application \# 553/CHENP/2006, coming from WO2005016894)—both disclosed Markush $^{26}$ group of compounds which individually destroyed novelty for Ceritinib molecule i.e. one would get/find the Ceritinib molecule in either of these documents, if one used the right substitutions. WO2005016894 had been cited in the original prosecution but the Controller, at that time, had allowed the claims during examination.

The Opponent also used these 2 documents and additionally 4999/KOLNP/2007 (coming from WO2007006926) to argue that the Ceritinib molecule lacked an inventive step.

Finally, the Opponent also argued that the Patentee did not provide any in vivo efficacy data for Ceritinib in comparison to compounds disclosed in these 2 documents and hence it failed the threshold of S.3(d) as Ceritinib would be a new form of known compounds in either of these filings.

The Controller's approval of the Markush filing destroying the novelty of later specific compounds in his decision is very interesting to this author since there are many other compound patent filings which fall in this template of an earlier Markush patent disclosing a large number of compounds and a later specific patent filing for the compound. This decision could potentially imply that the earlier broad Markush patent disclosures can be used to invalidate later specific compound patent filings.

Note: The Patentee filed an appeal against the Controller's revocation decision, at the IPAB. In July 2020, the IPAB has issued a 'stay' on the Controller's revocation $\operatorname{order}^{27}$ as an interim order in the appeal proceedings.

\footnotetext{
${ }^{26}$ Refer earlier note for definition of 'Markush' claims.

${ }^{27}$ A copy of the IPAB Order is available at https://ipab.gov.in/ipab_orders/delhi/MP.NO.8.2019OA.20.2019.PT.DEL.pdf.
} 


\subsection{The Viread Oppositions}

Tenofovir Disoproxil Fumarate (brand name: Viread) is used in treatment of AIDS and Hepatitis B. Gilead had filed a bunch of patent applications related to its Viread IP portfolio for-Tenofovir Disoproxil (ester) and the final product-Tenofovir Disoproxil Fumarate (salt form of the ester). Tenofovir had been invented years earlier by a Czech scientist ${ }^{28}$ and later Gilead + UC San Francisco carried out additional work. Finally, Gilead developed the salt form that finally became the block-buster HIV drug.

Some interesting facets to the Gilead Viread Indian patent portfolio:

- Gilead filed a large number of divisional filings from the 2 original filingseventually turning into multiple 'children'/'grandchildren' filings.

- Multiple companies, civil society and patient groups filed pre-grant oppositions in 2006 and onwards against most of these filings, over the years, including the divisional filings.

- Gilead secured a process patent in 2004 (IN190780 from the 1998 Fumarate filing) and later went on to complete a series of bilateral licenses with multiple Indian generic companies for making and supplying Tenofovir and its combination products for HIV for multiple countries, including India.

While many Indian companies went ahead with the royalty bearing license agreements around 2007, companies like Cipla did not take the license and continued with the opposition. It is worth nothing that except the original process grant, Gilead lost out in the compound oppositions - on both the ester and salt patent application series. Gilead also modified the license structure when it was argued that the original bilateral license template covered language that would stop companies from opposing Gilead' patents—a position that was specifically barred in Indian patent law. Table 5 summarizes the tenofovir opposition.

Over the years, Gilead has transformed its TDF licensing program from bilateral licenses to eventually moving onto the Medicine Patent Pool (MPP) multi-lateral license platform. The number of countries has also modified over the years with some critics arguing that the licenses exclude important middle income countries from the license ambit. ${ }^{29}$

It must always be remembered that Gilead' first interaction in India was the genesis of many later developments-mass pharmaceutical patent licensing, market segmentation and targeted exclusion of generics from middle income countries,

\footnotetext{
${ }^{28} \mathrm{https}: / /$ www.latimes.com/business/la-fi-gilead-timeline-20160527-snap-story.html.

${ }^{29} \mathrm{https}$ ://www.bizjournals.com/sanfrancisco/blog/biotech/2011/07/gilead-hiv-aids-quad-indiaafrica.html.
} 
Table 5 Tenofovir opposition

\begin{tabular}{l|l}
\hline Drug: & Tenofovir \\
\hline Therapeutic area: & HIV \\
\hline $\begin{array}{l}\text { Nature of patent filings } \\
\text { in India: }\end{array}$ & $\begin{array}{l}\text { Prodrug of Tenofovir \& } \\
\text { Salt of above prodrug }\end{array}$ \\
\hline Patent/Application \# & $\begin{array}{l}\text { (a) Tenofovir Disoproxil—an ester prodrug of tenofovir (2076/DEL/ } \\
\text { 1997) } \\
\text { (b) Tenofovir Disoproxil Fumarate (TDF)—a salt form of Tenofovir } \\
\text { Disoproxil (896/DEL/2002—this itself came as a divisional applica- } \\
\text { tion from 2174/DEL/1998) }\end{array}$ \\
\hline Opponents: & $\begin{array}{l}\text { Indian Network of People Living with HIV/AIDS (INP+) } \\
\text { Delhi Network of People Living with HIV/AIDS (DNP+) } \\
\text { Cipla Ltd. }\end{array}$ \\
\hline Expiry, if granted: & $\begin{array}{l}\text { 25/July/2017 for the ester form and } \\
\text { 24/July/2018 for the salt form }\end{array}$ \\
\hline Unique points: & Filing of multiple divisional applications, S.3(d)
\end{tabular}

expanding license program for later drugs to gain market acceptance (Gilead loaded a lot of its later drugs onto the TDF license).

Observers opine that the Gilead licensing program is a fairly successful program for most stakeholders. The MPP platform' ${ }^{30}$ status today as the major licensing platform covering HIV, Hepatitis and other drugs-is arguably due to Gilead's early move to that platform. The MPP platform has now become a template for most of later HIV drug licenses and Gilead and many other companies extensively license their IP across multiple drug categories, mostly for developing and least developed countries.

\subsection{Kaletra Opposition}

We now look at another opposition worth noting-this too was not a routine opposition against compounds, salts or polymorphs. This was an opposition against Abbotts' (now Abbvie) application covering its formulation technology platform to make heat stable tablets of various HIV drugs (see Table 6). Abbott's product (brand name Kaletra) was originally a soft gelatin capsule containing a fixed-dose of 2 drugs-Lopinavir and Ropinavir, used in the treatment of HIV. The new platform made it possible to make solid oral tablet formulation, instead of the earlier soft gelatin capsules. The earlier capsule had some limitations in terms of storage/ handling etc.

This opposition is extremely significant from a drug access perspective since the underlying technology platform is the basis for supply of heat stable formulations of

\footnotetext{
${ }^{30}$ For list of available drug patent licenses on the MPP platform, visit: https://medicinespatentpool. org/what-we-do/global-licence-overview/licences-in-the-mpp/.
} 
Table 6 Ritonavir and Lopinavir opposition

\begin{tabular}{l|l}
\hline Drug: & Ritonavir and Lopinavir \\
\hline Brand: & Kaletra \\
\hline Therapeutic area: & Anti HIV \\
\hline Nature of filings in India: & Formulation platform to make heat stable tablets of various drugs \\
\hline Application \# & $1.339 / M U M N P / 2006$ and its 2 divisionals: \\
& 2. 726/MUMNP/2009 and \\
\hline Date of decision: & 30/Dec/2010 \\
\hline Opponents: & Matrix Laboratories Limited, I-MAK, Cipla Ltd. and Okasa Pvt. Ltd. \\
\hline Expiry, if granted: & 23/Aug/2024 \\
\hline Unique points: & Filing of multiple divisional applications, obviousness. \\
\hline
\end{tabular}

various HIV drugs-which is how multiple drugs can be given in tablet form across many high temperature countries (especially as the African countries have a very high presence of HIV-AIDS). This technology platform allowed making heat stable tablets of the drug Ritonavir (and additional drugs) dissolved within a polymer versus the earlier generation soft gelatin capsules that were not heat stable and hence, had this application been granted in India, it would have given Abbott/Abbvie a monopoly on the entire heat stable platform which today covers all Ritonavir based combinations - e.g., Ritonavir + Lopinavir, Ritonavir + Atazanavir etc. Abbvie also uses this platform today for its Hepatitis drug tablets.

Companies had launched generic versions of combination tablet in India and other countries during the time the opposition was going on. So, the opposition paved the way for securing continued marketing of multiple heat stable drug formulations in India and other developing countries.

There were multiple arguments used including anticipation (including Abbott's own poster presentations and previous patent filings as anticipating the claimed tablet invention). While the opponents lost out arguments under S.3(d), S.3 (e) [admixture of known substances] and insufficient description, the Patent Office went ahead and rejected the application on the grounds of anticipation and lacking an inventive step, in late 2010.

One key fact that is not well known publicly is that the Applicant also filed multiple divisionals during the prosecution-including on the day of the parent application's opposition hearing. Interestingly, the Applicant filed not one divisional but two divisionals - at two different branches of the Patent Office in two different cities. Eventually, these divisionals were abandoned but not before the fact of the divisional filings in different cities was highlighted to the Controller. ${ }^{31}$

\footnotetext{
${ }^{31}$ For more information on the various divisional filings, refer:"Ever-greening: A status check in selected countries" (Journal of Generic Medicines (2010) 7, 227-242. DOI: 10.1057/jgm.2010.14).
} 
Table 7 Atazanavir Sulphate opposition

\begin{tabular}{l|l}
\hline Drug: & Atazanavir Sulphate \\
\hline Therapeutic area: & Anti HIV \\
\hline Nature of filing in India: & Process to make the Sulphate salt/crystals from Atazanavir \\
\hline Application \# & $6425 /$ DELNP/2006 \\
\hline Date of decision & 20/Dec/2010 \\
\hline Expiry, if granted: & 03/May/2015 \\
\hline Opponents: & Matrix Laboratories, Cipla Ltd. \\
\hline Unique points: & Obvious to try, insufficiency of disclosure and S.3(d) \\
\hline
\end{tabular}

\subsection{Reyataz Opposition}

The next opposition is worth noting against a Bristol Myers' patent application for a commercially relevant process to make the Sulphate salt of Atazanavir. Bristol Myers' sells an oral formulation of Atazanavir Sulphate under the brand name: Reyataz.

This decision is important because it highlights the position that generic companies keep a keen watch on not only the product/salt applications but also track and file detailed and strong oppositions against commercially sensitive process invention claims. Indian companies had launched generic version of this drug much before the opposition was finally adjudicated.

Apart from the standard approach for arguing obviousness (i.e. the process to make unique crystals of Atazanavir Sulphate from Atazanavir) based on prior art of Atazanavir and state of art, an interesting obviousness argument used here was that a process to make the Sulphate salt of an anti-coagulant drug (Clopidogrel to Clopidogrel Bisulphate) could lead to claims for making the Sulphate salt of Atazanavir, as lacking an inventive step. This was another 'obvious to try' argument by bringing in analogous prior art related to a different drug, but from overall field of developing synthetic processes for crystals of drugs. This 'obvious to try' argument, along with the other arguments, succeeded at the Patent Office. See Table 7.

\subsection{Combivir Opposition}

Combivir is Glaxo's brand product for an oral fixed-dose combination of Lamivudine and Zidovudine, used in the treatment of HIV infection. NGOs had filed a pre-grant opposition (see Table 8) this filing in March $2006^{32}$ at the Kolkata Patent Office, stating the drug was not a new invention.

\footnotetext{
${ }^{32} \mathrm{https} / / /$ www.msf.org/patent-application-aids-drug-opposed-first-time-india.
} 
Table 8 Combivir opposition

\begin{tabular}{l|l}
\hline Drug: & Fixed dose combination of two existing drugs: Zidovudine and Lamivudine \\
\hline $\begin{array}{l}\text { Therapeutic } \\
\text { area: }\end{array}$ & Anti-HIV \\
\hline Application \# & 2044/CAL/1997 \\
\hline Link & A copy of the opposition as filed, is available here \\
\hline $\begin{array}{l}\text { Expiry, if } \\
\text { granted: }\end{array}$ & 29/Oct/2017 \\
\hline Opponents: & $\begin{array}{l}\text { Indian Network for People Living with HIV/AIDS and the Manipur Network of } \\
\text { Positive People }\end{array}$ \\
\hline Unique point: & Applicant abandoned after civil society opposition \\
\hline
\end{tabular}

After this opposition, Glaxo withdrew its patent application in Aug $2006^{33}$ in India and Thailand ${ }^{34}$ and this removed the threat of a patent infringement suit against generic companies, in these 2 countries. The withdrawal meant that further oppositions were not required. Combivir was not the only Glaxo HIV/AIDS medical product that was opposed and this later resulted in more patent application(s) being abandoned by Glaxo.

\subsection{Trizivir Opposition}

Trizivir is an oral fixed-dose combination of 3 drugs-Lamivudine, Zidovudine and Abacavir Sulphate by Glaxo, used for the treatment of HIV infection. In October 2007, Glaxo withdrew its Indian application for Trizivir, after an opposition (see Table 9) was filed. Glaxo stated ${ }^{35}$ that "the company's move is in public interest and is part of its policy of routine review of patent applications."

\subsection{Ziagen Opposition}

Ziagen is a Glaxo product for the treatment of HIV, consisting Abacavir Sulphate. Glaxo abandoned its patent application for the Hemisulphate salt of Abacavir, after an opposition (see Table 10) was filed.

Per the author's checks, Indian companies had launched generic version of the above 3 Glaxo' medicines even before the abandonment actions by Glaxo.

\footnotetext{
${ }^{33} \mathrm{https} / / /$ economictimes.indiatimes.com/industry/healthcare/biotech/pharmaceuticals/gsk-with draws-patent-application-for-aids-drug/articleshow/1912871.cms.

${ }^{34}$ http://www.twn.my/title2/intellectual_property/info.service/twn.ipr.info.090603.htm.

${ }^{35} \mathrm{https}: / /$ www.livemint.com/Home-Page/kx90Ckvbspy4ApeAOxPFZP/GSK-withdraws-Trizivirpatent-application-8216in-public-i.html.
} 
Table 9 Trizivir opposition

\begin{tabular}{l|l}
\hline Drug: & Combination of 3 drugs: Lamivudine, Zidovudine and Abacavir Sulphate \\
\hline Therapeutic area: & Anti-HIV \\
\hline Application \# & IN/PCT/00/00521 \\
\hline Expiry, if granted: & 26/April/2019 \\
\hline Opponent: & Cipla Ltd. \\
\hline Unique point: & Applicant abandoned after pre-grant opposition \\
\hline
\end{tabular}

Table 10 Abacavir Sulphate opposition

\begin{tabular}{l|l}
\hline Drug: & Abacavir Sulphate \\
\hline Therapeutic area: & Anti-HIV \\
\hline Application \# & $872 /$ CAL/98 \\
\hline Opponent: & Indian Network of People Living with HIV/AIDS (INP+) \\
\hline Expiry, if granted: & $14 /$ May/2018 \\
\hline Copy of decision: & Image, here. \\
\hline Unique point: & Applicant abandoned after civil society opposition \\
\hline
\end{tabular}

\subsection{Isentress Opposition}

Merck had filed a patent application for the Potassium salt of Raltegravir. Merck sells this product under the brand 'Isentress'.

Cipla has been selling a generic version of Raltegravir in India, for the last few years. Three separate pre-grant oppositions (see Table 11) were filed against this application. The first opposition was filed in 2011 and the last one in late 2018. The oppositions did not see any traction for many years. When the Patent Office finally called all parties for a hearing in Aug 2020, Applicant (Merck) sent a letter-less than a week before hearing date-stating that they were not interested in pursuing the application, any further.

\subsection{Sanofi TB Drugs Oppositions}

Sanofi had filed two patent applications in India pertaining to anti-tuberculosis drug formulations for therapies known as 3HP and 3RH. The two applications covered two different formulations of known TB 2 drugs (Isoniazid and Rifapentine). One application covered a film coated formulation and the other application covered a dispersible (pediatric) formulation of the 2 drugs.

Civil society groups have been advocating to Sanofi on these patents. They filed oppositions (see Tables 12 and 13) in November 2019-first in India and then in 
Table 11 Raltegravir Potassium opposition

\begin{tabular}{l|l}
\hline Drug: & Raltegravir Potassium \\
\hline Therapeutic area: & Anti HIV \\
\hline Nature of filing in India: & Potassium salt of Raltegravir; crystals of the salt \\
\hline Application \# & $4187 /$ DELNP/2007 \\
\hline Expiry, if granted: & 02/Dec/2025 \\
\hline Opponents: & $\begin{array}{l}\text { Indian Network for People Living with HIV/AIDS, } \\
\text { Delhi Network of Positive People and } \\
\text { Mylan Laboratories Limited }\end{array}$ \\
\hline Unique point: & Applicant abandoned after civil society opposition \\
\hline
\end{tabular}

Table 12 Isoniazid and Rifapentine opposition

\begin{tabular}{l|l}
\hline Drug: & Dispersible combination formulation of Isoniazid and Rifapentine \\
\hline Therapeutic area: & Anti-Tuberculosis \\
\hline Application \# & IN201637002758 \\
\hline Expiry, if granted: & 22/July/2034 \\
\hline Opponent: & Delhi Network of People Living with HIV/AIDS (DNP+) \\
\hline
\end{tabular}

Table 13 Isoniazid and Rifapentine opposition (different formulation)

\begin{tabular}{l|l}
\hline Drug: & Film coated combination formulation of Isoniazid and Rifapentine \\
\hline Therapeutic area: & Anti-Tuberculosis \\
\hline Application \# & IN201637002757 \\
\hline Expiry, if granted: & 22/July/2034 \\
\hline Opponent: & Delhi Network of People Living with HIV/AIDS (DNP+) \\
\hline
\end{tabular}

Thailand ${ }^{36}$ and have also written letters asking Sanofi to abandon the patent families. After the oppositions were filed, Sanofi withdrew both application families in many countries. The application families were first withdrawn at the EPO, then Indonesia ${ }^{37}$ and later in India ${ }^{38}$ (February 2020). In August 2020, Sanofi formally confirmed that it was abandoning all patent filings relating to these 2 applications. ${ }^{39}$

As noted in the multiple instances above, many patent applicants, especially from the HIV domain, abandon their secondary patent applications (i.e. those related to process, salt or crystal forms) once they face pre-grant oppositions or once civil society groups start a public action on such drugs. It can be argued that the such later

\footnotetext{
${ }^{36} \mathrm{https}: / / \mathrm{www}$.treatmentactiongroup.org/statement/sanofi-withdraws-two-patent-applications-onlife-saving-tuberculosis-prevention-drugs-in-europe-and-in-indonesia/.

${ }^{37} \mathrm{https}$ ://www.rouse.com/magazine/news/sanofis-tb-patents-dispute-overflows-to-indonesia/? tag $=$ indonesia.

${ }^{38}$ Refer information tweeted at: <https://twitter.com/achayansz/status/1245229743521370112>.

${ }^{39}$ Refer Sanofi's letter dated 04/August/2020, to Treatment Action Group, available at: <https:// www.treatmentactiongroup.org/wp-content/uploads/2020/08/tag_otmeds_sanofi_patent_with drawals_RESPONSE.pdf $>$.
} 
Table 14 Remdesivir opposition

\begin{tabular}{l|l}
\hline Drug: & Remdesivir \\
\hline Therapeutic area: & CoVid-19 \\
\hline Patents \# & $\begin{array}{l}\text { IN275967 (from 7068/DELNP/2010) } \\
\text { IN332280 (from IN201727012821) }\end{array}$ \\
\hline Petitioner(s) & $\begin{array}{l}\text { (i) Cancer Patients Aid Association (CPAA) } \\
\text { (ii) Campaign for Access to Affordable Medicines, Diagnostics and } \\
\text { Devices, India (CAMeD-India) + Third World Network (India) }\end{array}$ \\
\hline Opponent: & (iii) LowCost Standard Therapeutics \\
\hline $\begin{array}{l}\text { Copy of request } \\
\text { letter: }\end{array}$ & $\begin{array}{l}\text { Copy of the Request letter dated 09/April/2020 is available at the CPAA } \\
\text { website } \\
\text { Copy of the Third World Network letter dated 13/May/2020 is available at } \\
\text { their website. }\end{array}$ \\
\hline
\end{tabular}

abandonment action is due to the patent applicant assessing the strength of its filing versus the legal arguments put forth by the pre-grant opponents [e.g. obviousness and S.3(d)] and the potential negative press related to drug access issues.

\subsection{Veklury Opposition}

The CoVid-19 pandemic has bought many drugs and issues surrounding drug access and patents, in the public limelight, at a scale, hitherto unseen. Gilead has at least 4 patents/patent applications pertaining to Remdesivir (Gilead brand: Veklury), in India. Amidst the global medical crisis, in April 2020, the Cancer Patients Aid Association ('CPAA') and later Third World Network (both being civil society organizations) asked the Government of India to revoke Gilead's granted Indian patent(s).

A post-grant opposition under section 25(2) was filed by a not-for-profit civil society organisation-LowCost Standard Therapeutics — on the patent (IN332280) in June 2020 (see Table 14). The petitions/letters did not opt for filing the standard post-grant opposition(s) under S.25(2) but sought revocation of the patent(s) under S.66 ('Revocation of patent in public interest' ${ }^{40}$ ).

CPAA filed the request for revoking one patent (IN332280) with the Ministry of Chemicals and Fertilizers as well as the Health Secretary for the Government of India.

\footnotetext{
${ }^{40}$ Text of S.66 is available at $<$ https://indiankanoon.org/doc/441313/>. It states:

66 Revocation of patent in public interest. -

Where the Central Government is of opinion that a patent or the mode in which it is exercised is mischievous to the State or generally prejudicial to the public, it may, after giving the patentee an opportunity to be heard, make a declaration to that effect in the Official Gazette and thereupon the patent shall be deemed to be revoked.
} 
The Campaign for Access to Affordable Medicines, Diagnostics and Devices, India (CAMD-India) and Third World Network (India) jointly wrote a separate request calling for revocation of two patents (IN275967 and IN332280) with the Department of Promotion of Industry and Internal Trade (DPIIT) (within the Ministry of Commerce \& Industry, Government of India).

The DPIIT supervises the functioning of the Patent Office. None of the Government ministries/departments have made any public statement on these letters as of end July, 2020. In July 2020, the Patent Office asked Gilead to respond to the LowCost Standard' opposition. Gilead filed its reply in Oct 2020. A final hearing on the Opposition has not yet been scheduled.

Starting May 2020, Gilead has signed voluntary licenses for manufacture and sale of Remdesivir in 127 countries (including India), with multiple companies (nine companies as of end July $2020^{41}$ ) on a 'zero royalty' basis, until the disease remains a pandemic. These bilateral licenses are a change in Gilead's strategy from the HIV multi-lateral licenses on the MPP platform. The Remdesivir license text is not available in the public domain.

\section{Pendency of Oppositions in the Indian Patent Office}

Oppositions can only help in increasing access if they are adjudicated in a timely and transparent fashion. So, while in the earlier section, we saw the monumental impact that pre-grant and post-grant oppositions had on drug access, it would be remiss if we do not look at some current ground realities.

The Government has over the last few years, multiple times, shown that it is focused towards higher number of patent grants ${ }^{42}$ but the author believes that adjudication of oppositions has been very slow at the Indian Patent Office, over the years.

We have two sources for numbers- the first are the annual reports published by the Patent Office. The Report for year ending March 2020 is not available on IPO site as of end December 2020. The CIPAM website ${ }^{43}$ is the second source for some of the numbers. A few years ago, Prashant Reddy (an Indian IP lawyer) tried to find out $^{44}$ the exact number of oppositions pending at the Indian Patent Office, using the information request pathway, but the exercise did not yield relevant results. The 2020 Numbers are courtsey SpicyIP website.

\footnotetext{
${ }^{41}$ Gilead's website discusses its Remdesivir licensing program here: <https://www.gilead.com/ purpose/advancing-global-health/covid-19/voluntary-licensing-agreements-for-remdesivir $>$.

${ }^{42} \mathrm{https}: / / \mathrm{m}$. economictimes.com/news/economy/indicators/grant-of-patents-up-12-per-cent-duringapril-december-fy19-dpiit/articleshow/68317795.cms.

${ }^{43}$ http://cipam.gov.in/iptrends/\#patent.

${ }^{44}$ For a detailed article on his exercise, do read his note at the SpicyIP blog, available here: $<$ https:// spicyip.com/2017/12/rtis-reveal-tardy-record-keeping-practices-at-the-ipo-no-records-of-pendingpatent-oppositions-113857-trademark-oppositions-pending-5533-rectifications.html > .
} 
The Patent Office has done a commendable job in terms of increasing the size of the Examiner cadre, increasing the number of applications examined, reducing the pendency of period taken to examine and grant a patent, but a deeper check reveals the potential opposition pendency numbers and that presents an alarming picture.

As will noted, the data is not complete. And even for items where the IPO releases numbers, there are internal inconsistencies.

\subsection{Pre-grant Oppositions}

- Post 2008-09, specific data for cumulative pre-grant oppositions pending at end of every year is not given in the Patent Office' Annual Reports. Hence, we do not know the number pre-grant oppositions pending on a cumulative basis, as per the IPO.

- For the latest 12-year period (FY 2007-8 through FY 2019-20), cumulatively $\sim 3600$ pre-grant oppositions have been filed while the cumulative disposal number is $\sim 950$ oppositions. This means, potentially, $64 \%$ pre-grant oppositions are, as yet, undecided as per my calculations (see Fig. 1).

- The number of 'new' pre-grant oppositions filed annually for last few years has been below 300 (with a sudden upward spike from FY 2018-19: 426 and going to a massive 800 in FY 2019-20). This trend, when considered with the larger increase in number of patent applications filed each year, would still imply that on a percentage basis, a lesser number of applications are now being opposed, each year.

- The annual pre-grant opposition disposal rate has not kept pace with trend of increased patent application filings or the number of examiners inducted, nor has

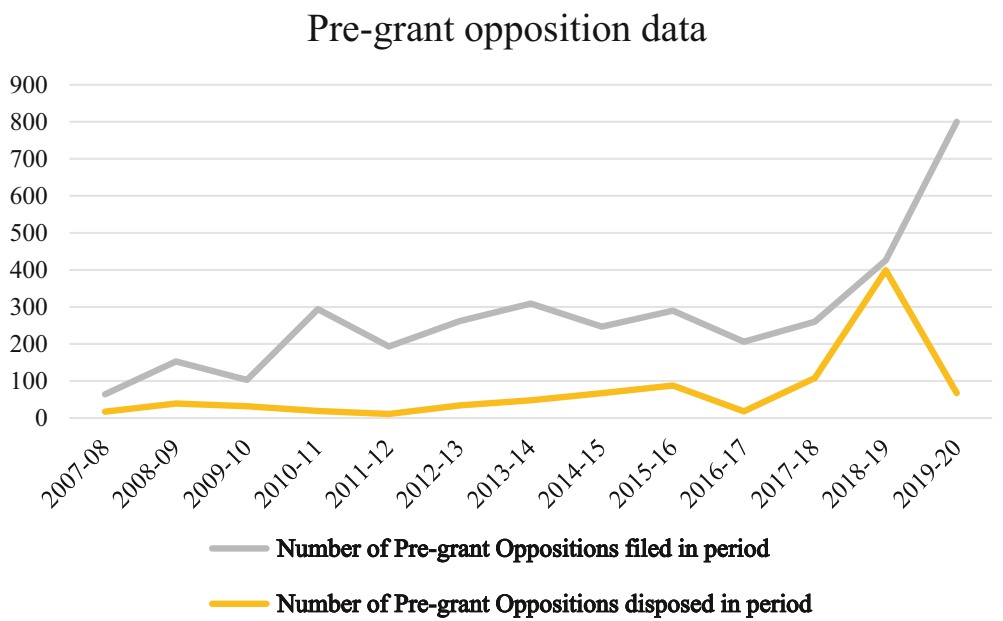

Fig. 1 Pre-grant opposition data 2007-2020 
it matched the pace of increase in new opposition filings. The disposal rate for year 2018-19 shows a sudden, huge upward unexplained spike: 399 and then a fall back to 67. This fall is in line with earlier trend of close to 100 or less pre-grant disposals annually. The one-time surprise figure of 399 pre-grant disposals in FY 2018-9 is an unexplainable mystery.

- For the same period, upon adding the numbers for pre-grant oppositions filed and reducing the annual pre-grant oppositions disposed (3607 less 947 equals 2660) and assuming that at least some of the pre-grant oppositions are duplicates against a single patent application or some oppositions may have been withdrawn, I believe that at least $1300+$ unique pre-grant total oppositions are still pending.

\subsection{Post-grant Oppositions}

- As at end of FY 2019-20, per the IPO, only 99 post-grant oppositions are pending on a cumulative basis. This differs drastically from my calculation (184)—which is based on simple addition/subtraction.

- For the latest 12 year period (FY 2007-8 through FY 2019-20), based on my calculation, cumulatively 310 post-grant oppositions have been filed while the cumulative disposal number is 126 oppositions (see Fig. 2).

- Around 10 post-grant oppositions are being disposed, annually for the last few years.

- The number of 'new' post-grant oppositions filed annually for last few years has been below 20 (with a sudden upward rise in last 2 years-28 each for last

Post-grant opposition data

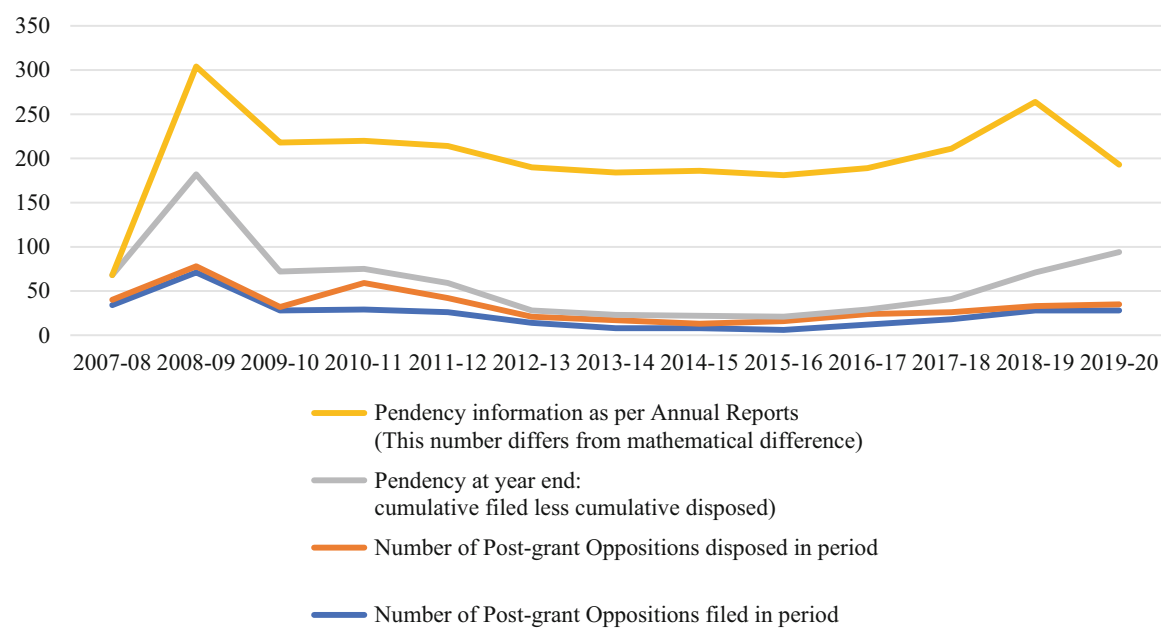

Fig. 2 Post-grant opposition data 2007-2020 
2 years) - which when considered with the large increase in number of patents granted, would again imply that on a percentage basis, comparatively lesser number of post-grant oppositions are now being filed every year.

- As per IPO annual report data, annual post-grant opposition pendency figure was below 170 for last few years. This high pendency number is also a cause of concern. However, the IPO data for pending post-grant opposition at year end is not completely understanding. For instance, for FY 2019-18: 193 pending and then for 2019-20 only 99 pending, but the IPO did not dispose 100 odd post-grant oppositions in FY 2019-20-so there is some confusion as to how the 193 pendency figure went down to only 99.

- The difference in the calculated pending cumulative post-grant oppositions 184 at end of FY 2019-20 versus the pending cumulative post-grant oppositions as per IPO (99) — cannot be easily explained but could possibly be due to some cases of multiple oppositions to a single patent or expiry of some patents before disposal, where no disposal decision was issued.

The number of patents granted has moved to approx. 25,000 grants for year ending March 2020 while the number of applications examined moved impressively by approx. 7 times (from $\sim 11,700$ to $\sim 80,000+$ ), with an approx. 3 times increase in the Examiner cadre (163 to 449$)$. Within these numbers, the contentious proceedings disposal pendency as mentioned by IPO (from 23 in 2007-8 (17 pre-grants +6 postgrants) to $\sim 74$ in 2019-20 (67 pre-grants +7 post-grants) continues to remain a cause of concern.

\subsection{Pendency at the Intellectual Property Appellate Board (IPAB)}

Appeals from IPO (for most items) needed to be filed at the IPAB. As of mid-2019, approx. 617 Patent cases were pending with IPAB. ${ }^{45}$ Even after starting various advertising initiatives on the importance of IP, it is glaring that the Government was consistently not able to keep the requisite bench strength at the IPAB, including the chairperson or the technical member (patents) at the IPAB.

As per a calculation done on SpicyIP, an Indian IP blog, 'in its 17 years of existence, the IPAB has not had a Chairperson for a cumulative total of 1130 days' ${ }^{46}$

The position of the Chairperson of the IPAB (i.e. the judicial member) was vacant for quite a long time and so the Supreme Court granted a fresh term in December

\footnotetext{
${ }^{45}$ Year wise pendency data is not available for the IPAB. These numbers have come from a court case: refer para 7 in Mylan Laboratories Limited v. Union of India $<$ https://indiankanoon.org/doc/ $58294410 />$.

${ }^{46} \mathrm{https}$ ://spicyip.com/2020/04/the-case-for-shutting-down-the-intellectual-property-appellateboard-ipab.html.
} 
2019 to the already retired judicial member. ${ }^{47}$ In a similar pattern, the position of the technical member (patents) was vacant since May 2016 and so, in July 2019, the Delhi High Court had then asked the technical member (plant variety protection) to look at the patent responsibilities. ${ }^{48}$

These judicial interventions show that recruitment of the senior-most IPAB functionaries was not done in time even when the government was aware of the normal tenure of such functionaries. Note: A new technical member (patents) was finally appointed in July 2020 and the process of recruiting a new chairperson (judicial member) to replace the current chairperson's whose extended term was to end in September 2020, had started. ${ }^{49}$

\subsection{Impact of Pendency}

The pendency number and dismal disposal for each component-pre-grant oppositions, post-grant oppositions and IPAB cases-is very worrying. The adjudication of pending oppositions (both pre-grant oppositions and post-grant oppositions) is a continuing challenge for the Patent Office. The rise in pre-grant disposals for 2018-19 needs to be understood and expanded upon. While the number of examiners at the Patent Office has trebled in the 3-year period, the numbers of controllers becoming Assistant or Deputy Controllers has not jumped by that percentage. It is the Controller who is at the center of managing the pre-grant and post-grant opposition process and finally adjudicating on the opposition and this could also be a reason for slower disposal.

The IPAB pendency position, for both proceedings and personnel, brings in a bigger question on the Government's willingness to work towards a quick and efficient IP dispute disposal system. Undecided oppositions/IPAB revocations mean that generic companies may not have the confidence to undertake at risk launches, due to the threat of damages. Likewise, delay in clearing pre-grant oppositions also hurts patent applicants as it chips away at the term of any future patent available to the applicant and at same time, keeps a sword hanging on opponents for years. The IPO's leadership must examine the pendency and should incentivize examiners and Controllers for faster adjudication of contentious proceedings. Examiners and Controllers today are assessed based on examinations and grants and if opposition adjudication can be kept as an independent performance target which can lead to faster professional growth inside the IPO, it could act as an incentive for proceedings being completed faster.

\footnotetext{
${ }^{47}$ https://images.assettype.com/barandbench/2019-12/829f572d-5ff5-421d-8a2ba10cc8d07727/ Supreme_Court__IPAB_Chairman_Order.pdf.

${ }^{48}$ Mylan, Ibid.

${ }^{49}$ Refer SpicyIP post: https://spicyip.com/2020/08/breaking-news-controller-generals-officeagrees-with-our-petition-for-scrapping-the-intellectual-property-appellate-board.html.
} 
Clearly, the present system for managing and adjudicating oppositions/IPAB matters, including timely recruitment, needs a major overhaul with time-bound proceedings and decision issuance being implemented for faster adjudication of oppositions. Urgent and immediate actions need to be undertaken by the Government to bring in requisite personnel, reduce pendency and increase disposal of oppositions and IPAB matters.

\section{Conclusion}

The pre-grant and post-grant oppositions filed by civil society organisations and generic companies-over the years have been instrumental in earlier launch of drugs, thereby increasing access of drugs not only for the Indian population-but also allowed export of drugs to other countries.

The filing (and winning) of these oppositions have been the pivot for earlier generic entry of many life-saving drugs. Oppositions have been instrumental in competitively priced generics. These oppositions not only led to generic products in India but also in a whole host of developing and least developed countries.

As we saw, the Indian oppositions have moved beyond the simple arguments of S.3(d) to more complex arguments and have seen fair bit of success.

Finally, the increasing pendency of oppositions over the last few years is a matter of deep concern and the current trend seems to imply that unless the Government strengthens the system by bringing in requisite number of personnel, the pendency numbers will not come down, substantially, in the near term.

\section{Author's Note}

The Indian opposition saga has been one of achieving path-breaking results through sheer advocacy and fighting spirit of the civil society organisations (NGOs). The massive efforts undertaken by these NGOs over the years in litigating against corporates with huge budgets must to be applauded, for the results achieved.

The author is deeply indebted to friends from the civil society and generic companies who willingly shared anecdotes and facts from these opposition battles. Most of them chose to remain anonymous for the purposes of this paper. The author thanks (in alphabetical order)-Swaraj Barooah, (Late) Shamnad Basheer, Adv. Julie George, Adv. Rajeshwari Hariharan, Adv. Feroz Ali Khader, Ms. Leena Menghaney, Adv. Guruswamy Nataraj and 
Prof. Bhaven Sampat for discussions over the years and friends who have reviewed draft versions of this paper.

The present paper is based on a talk given by the author at the invitation of the South Centre and the Max Planck Institute for Innovation and Competition at the 'Global Forum on Intellectual Property, Access to Medicines and Innovation' held at Munich in Dec 2019. The author thanks the South Centre (and its wonderful team-Dr. Carlos Correa, Dr. German Velasquez, Dr. Viviana Munoz and Mr. Nirmalya Syam) and Professor Dr. Reto M. Hilty at the Max Planck Institute for Innovation and Competition, for the opportunity.

\section{Conflict Declaration/Disclaimer}

The author has been employed within the generic pharmaceutical industry for 18 plus years and was professionally involved in some of the opposition cases, discussed in this paper. The paper is based on information available in public domain as of 31/Dec/2020 and discussions with multiple stakeholders, over many years. All website links have been last accessed on the same date.

Errors, if any, are the sole responsibility of the author. The views, observations and submissions presented in this paper are entirely personal and should not be attributed or construed to reflect the views of the author's present or past employer(s). 


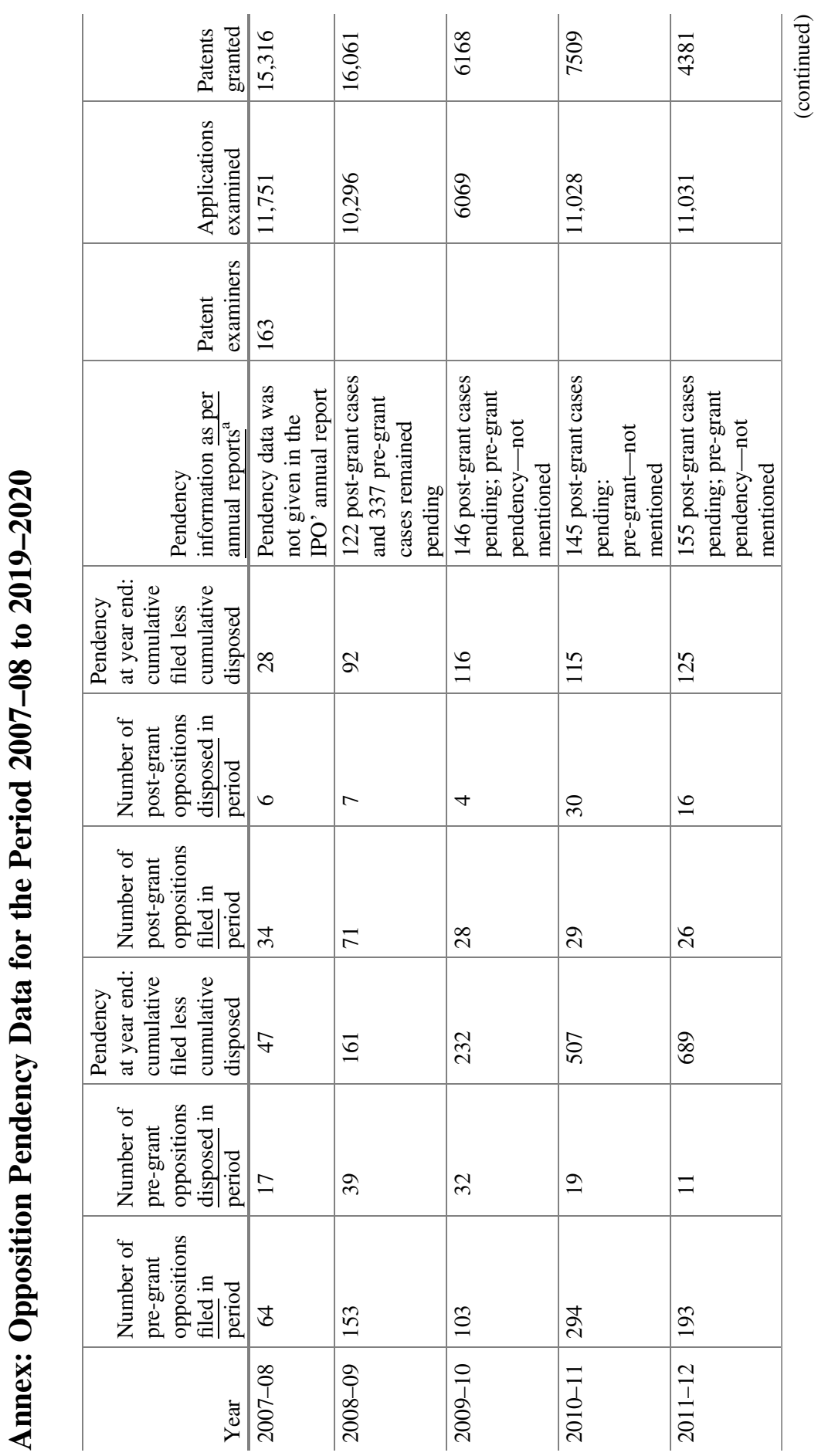




\begin{tabular}{|c|c|c|c|c|c|c|}
\hline 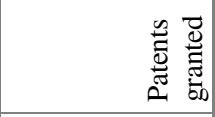 & $\frac{\stackrel{Ð}{\mathcal{V}}}{\forall}$ & సิ & $\begin{array}{l}\infty \\
\frac{\infty}{a} \\
\text { in }\end{array}$ & $\begin{array}{l}0 \\
\text { స్ర }\end{array}$ & 衣 & 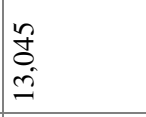 \\
\hline 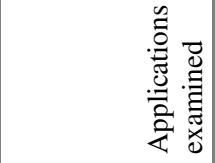 & 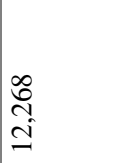 & $\begin{array}{l}n \\
0 \\
\infty \\
-1\end{array}$ & $\begin{array}{l}\bar{\delta} \\
\text { i }\end{array}$ & $\begin{array}{l}\bar{\sigma} \\
\infty \\
0 \\
0\end{array}$ & 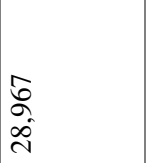 & 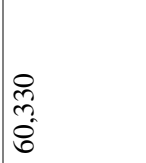 \\
\hline 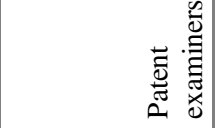 & & & & $\stackrel{2}{2}$ & $\stackrel{\infty}{\stackrel{\wp}{\sim}}$ & $\underset{i n}{N}$ \\
\hline 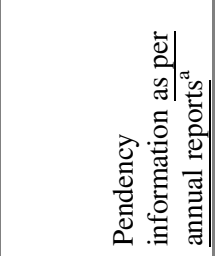 & 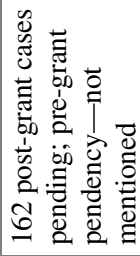 & 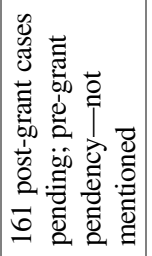 & 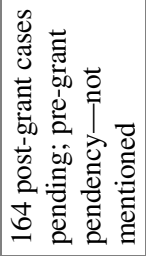 & 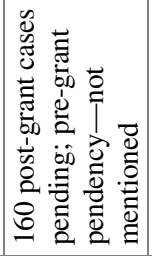 & 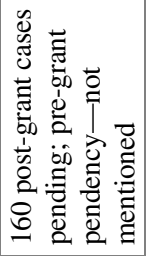 & 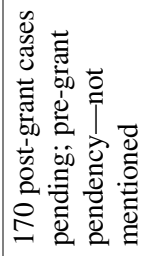 \\
\hline 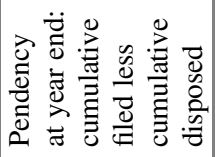 & 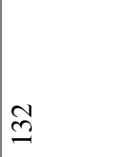 & $\bar{n}$ & $\stackrel{+}{=}$ & 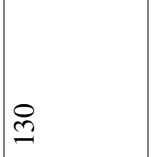 & $\stackrel{\ominus}{=}$ & $\stackrel{\text { I }}{I}$ \\
\hline 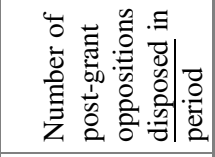 & $r$ & $a$ & $n$ & & $\simeq$ & $\infty$ \\
\hline 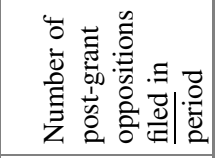 & \pm & $\infty$ & $\infty$ & 6 & $\simeq$ & $\stackrel{\infty}{-}$ \\
\hline 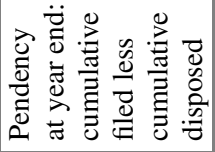 & $\frac{5}{a}$ & $\stackrel{\infty}{\stackrel{\infty}{\Xi}}$ & $\begin{array}{l}\infty \\
\stackrel{\infty}{2} \\
2\end{array}$ & 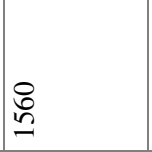 & $\stackrel{\infty}{\stackrel{\infty}{I}}$ & § \\
\hline 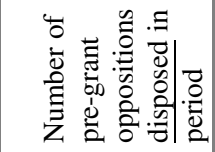 & চे & $\stackrel{\infty}{+}$ & $\hat{0}$ & $\infty$ & $\infty$ & $\stackrel{\infty}{\varrho}$ \\
\hline 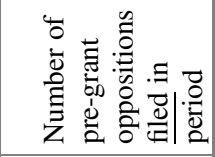 & ָे & ᄋे & 卞 & ঐ) & 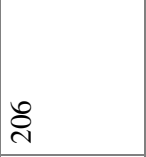 & $\stackrel{8}{\circ}$ \\
\hline$\stackrel{\circlearrowright}{\stackrel{D}{*}}$ & $\begin{array}{l}m \\
\stackrel{1}{1} \\
\stackrel{2}{2}\end{array}$ & 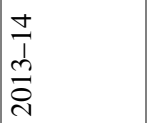 & $\begin{array}{l}n \\
\frac{1}{1} \\
d \\
\stackrel{d}{1}\end{array}$ & $\begin{array}{l}0 \\
1 \\
n \\
\check{2} \\
\text { d }\end{array}$ & $\begin{array}{l}n \\
1 \\
b \\
0 \\
\text { n }\end{array}$ & $\frac{\infty}{1}$ \\
\hline
\end{tabular}




\begin{tabular}{|c|c|c|}
\hline 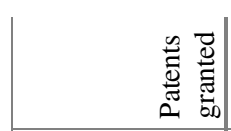 & & $\begin{array}{l}\stackrel{0}{\circ} \\
\stackrel{\sigma}{\sim}\end{array}$ \\
\hline 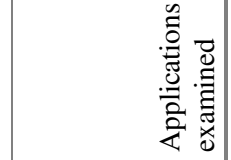 & 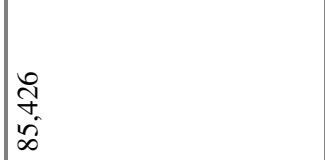 & $\begin{array}{l}\infty \\
\infty \\
0 \\
\infty\end{array}$ \\
\hline 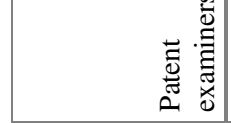 & 守 & \\
\hline 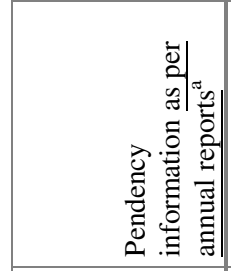 & 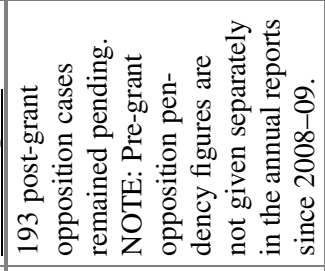 & 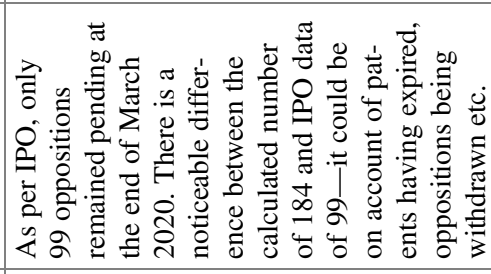 \\
\hline 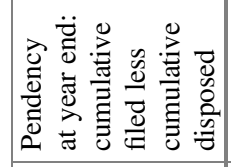 & $\underline{6}$ & $\stackrel{ \pm}{-}$ \\
\hline 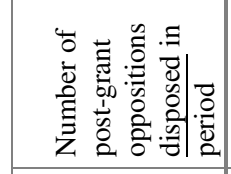 & in & - \\
\hline 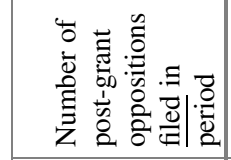 & $\infty$ & $\stackrel{\infty}{\sim}$ \\
\hline 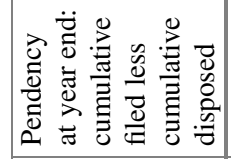 & $\widehat{\widehat{a}}$ & : \\
\hline 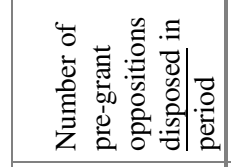 & ले & $\hat{\sigma}$ \\
\hline 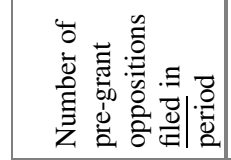 & 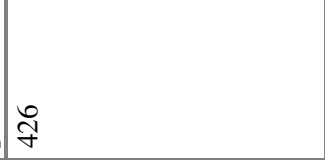 & $\underset{\infty}{~}$ \\
\hline 营 & 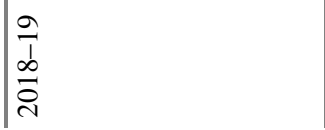 & 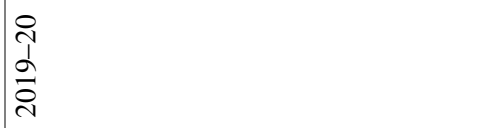 \\
\hline
\end{tabular}




\section{References}

Ali F (2016) Open prosecution: towards ex ante validation of patents. Available at SSRN: https:// ssrn.com/abstract $=2755189$ or https://doi.org/10.2139/ssrn.2755189

Ali F, Rajagopal S, Raman VS, John R (2018) Pharmaceutical patent grants in India: how our safeguards against evergreening have failed, and why the system must be reformed. Available at $<$ https://accessibsa.org/media/2018/04/Pharmaceutical-Patent-Grants-in-India.pdf >

Amin T (2010) Re-visiting the patents and access to medicines dichotomy: an evaluation of TRIPS implementation and public health safeguards in developing countries. In: Aginam O, Harrington J, Yu P (eds) Global governance of HIV/AIDS: intellectual property and access to essential medicines. Edward Elgar. SSRN: https://ssrn.com/abstract=1573723 or https://doi. org/10.2139/ssrn. 1573723

Attaran A (2014) A modest but meaningful decision for Indian Drug Patents (August 9, 2014). Lancet 384:477-479. Available at SSRN: https://ssrn.com/abstract $=2747623$

Basheer S, Reddy P (2008) "Ducking" TRIPS in India: a saga involving Novartis and the legality of Section 3(d). Natl Law School India Rev 20(2):131-155

EWHC 1094 (Pat), available at https://www.bailii.org/ew/cases/EWHC/Patents/2014/1094.html

Financial Times, Roche drops patent for Herceptin in India. https://www.ft.com/content/b8c9cf060676-11e3-9bd9-00144feab7de

Gilead, Voluntary Licensing Agreements for Remdesivir. < https://www.gilead.com/purpose/ advancing-global-health/covid-19/voluntary-licensing-agreements-for-remdesivir>

Grant of patents up 12 per cent during April-December FY'19: DPIIT, 8 March 2019. https://m. economictimes.com/news/economy/indicators/grant-of-patents-up-12-per-cent-during-aprildecember-fy19-dpiit/articleshow/68317795.cms

Grebe E, Low M (2017) The global movement around the Imatinib Mesylate case and its roots in the AIDS movement (April 23, 2017) Revised version of CSSR Working Paper No. 349. Available at SSRN: https://ssrn.com/abstract $=2546392$

Ho CM (2011) Freedom under TRIPS: India as an example. In: Access to medicine in the global economy: international agreements on patents and related rights. Oxford University Press, Loyola University Chicago School of Law Research Paper No. 2011-025. Available at SSRN: https://ssrn.com/abstract $=1921583$

Krishnan V (2013) Roche lost Herceptin patent due to procedural problems, 13 Aug 2013. https:// www.livemint.com/Companies/TBQxokHyVTMGozu78o6CSL/India-partly-revokes-Rochecancer-drug-patent.html

Melody Petersen A history of Gilead's biggest HIV drug, 29 May 2016. https://www.latimes.com/ business/la-fi-gilead-timeline-20160527-snap-story.html

MSF, Patent application for AIDS drug opposed for first time in India, Press Release 30 March 2006. https://www.msf.org/patent-application-aids-drug-opposed-first-time-india

Mylan Laboratories Limited v. Union of India. https://indiankanoon.org/doc/58294410/

Mylan launches first Trastuzumab biosimilar in India, 4 February 2014. https://www. thehindubusinessline.com/companies/mylan-launches-first-trastuzumab-biosimilar-in-india/arti cle23122107.ece

Nick Redfearn Sanofi's TB patents dispute overflows to Indonesia, Rouse, 29 January 2020. https:// www.rouse.com/magazine/news/sanofis-tb-patents-dispute-overflows-to-indonesia/? tag=indonesia

Novartis AG v. Union of India \& Ors. [2013] INSC 369. Available at: <https://www. globalhealthrights.org/wp-content/uploads/2013/04/SC-2013-Novartis-AG-v.-Union-of-India. pdf $>$ 
Ragavan S (2013) The patent failure of Novartis with Gleevec, Note on Novartis v. Union of India Judgment. Wegner's Writings (Blog by Hal Wegner). Available at: http://works.bepress.com/ srividhya_ragavan/156/

Rathod SK (2010) Ever-greening: a status check in selected countries. J Generic Med 7(3):227-242. https://doi.org/10.1057/jgm.2010.14

'Report on the revision of the patents law' by Justice N. Rajagopala Ayyangar; released in September 1959 and available at $<$ http://www.ipindia.nic.in/writereaddata/Portal/Images/pdf/ 1959-_Justice_N_R_Ayyangar_committee_report.pdf >

Reuters, Roche gives up on India patent for breast cancer drug, 16 August 2013. https://www. reuters.com/article/us-roche-herceptin-india/roche-gives-up-on-india-patent-for-breast-cancerdrug-idUSBRE97F08220130816

Sampat BN, Shadlen KC (2018) Indian pharmaceutical patent prosecution: the changing role of Section 3(d). PLoS ONE 13(4):e0194714. https://doi.org/10.1371/journal.pone.0194714

Serrano O, Burri M (2019) TRIPS implementation in developing countries: likely scenarios to 2025. In: Elsig M, Hahn M, Spilker G (eds) The shifting landscape of global trade governance. Cambridge University Press, pp 275-294. Available at SSRN: https://ssrn.com/ abstract $=3380246$

The Business Journals, Gilead boosts low-cost HIV drug deal in developing countries, 12 July 2011. https://www.bizjournals.com/sanfrancisco/blog/biotech/2011/07/gilead-hiv-aids-quadindia-africa.html

The Economic Times, GSK withdraws patent application for AIDS drug, 21 August 2006. https:// economictimes.indiatimes.com/industry/healthcare/biotech/pharmaceuticals/gsk-withdraws-pat ent-application-for-aids-drug/articleshow/1912871.cms

The Economic Times, SC asks Chennai patent office to hear Roche, https://economictimes. indiatimes.com/industry/healthcare/biotech/pharmaceuticals/sc-asks-chennai-patent-office-tohear-roche/printarticle/4213952.cms

The Office of the Controller General off Patents, Designs, Trade Marks And Geographical Indications, Annual Report 2018-19. http://www.ipindia.nic.in/writereaddata/Portal/Images/pdf/ IP_India_Annual_Report_2019_Eng.pdf

Third World Network, GSK withdraws Combivir patent application from India and Thailand, 12 September 2006. http://www.twn.my/title2/intellectual_property/info.service/twn.ipr.info. 090603.htm

Treatment Action Group Sanofi Withdraws Two Patent Applications on Life-Saving Tuberculosis Prevention Drugs in Europe and in Indonesia, 22 January 2020. https://www. treatmentactiongroup.org/statement/sanofi-withdraws-two-patent-applications-on-life-savingtuberculosis-prevention-drugs-in-europe-and-in-indonesia/

USPTO, Markish Claims https://www.uspto.gov/web/offices/pac/mpep/s2117.html

Open Access This chapter is licensed under the terms of the Creative Commons Attribution 4.0 International License (http://creativecommons.org/licenses/by/4.0/), which permits use, sharing, adaptation, distribution and reproduction in any medium or format, as long as you give appropriate credit to the original author(s) and the source, provide a link to the Creative Commons license and indicate if changes were made.

The images or other third party material in this chapter are included in the chapter's Creative Commons license, unless indicated otherwise in a credit line to the material. If material is not included in the chapter's Creative Commons license and your intended use is not permitted by statutory regulation or exceeds the permitted use, you will need to obtain permission directly from the copyright holder.

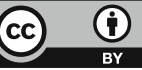

